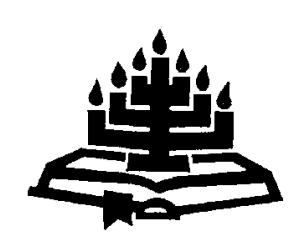

\title{
Op soek na 'n weg uit fundamentalisme, rasionalisme en relatiwisme
}

\author{
N. Vorster \\ Skool vir Kerkwetenskappe \\ Potchefstroomkampus \\ Noordwes-Universiteit \\ POTCHEFSTROOM \\ E-pos: nvorster@telkomsa.net
}

\begin{abstract}
Looking for a way out of fundamentalism, rationalism and relativism

The question this article poses is how the extremes of theological fundamentalism, rationalism and relativism can be avoided without compromising the authority of Scripture. The central theoretical argument of this article is that theological extremism can be avoided, should a plurality of methods be used - i.c. methods which are author, text and reader orientated. An acceptable theological framework should also be created to enable the theologian to interpret the Bible in such a way that conclusions arrived at can be checked and onesidedness be avoided. Such a framework should take into account the relational scope of Scripture, the contours of Scripture itself and the historical nature of biblical material. A balanced relation between the divine and the human nature of Scripture should be maintained and Scripture should be approached from the perspective of the covenant. In its contextualisation Scripture should not be seen as a document providing instant solutions to every problem, but as a paradigmatic document outlining basic contours according to which contemporary problems can be approached.
\end{abstract}

\section{Opsomming}

Op soek na ' $n$ weg uit fundamentalisme, rasionalisme en relatiwisime

Die vraag wat in hierdie artikel bespreek word, is hoe die uiterstes van teologiese fundamentalisme, rasionalisme en relatiwisme vermy kan word sonder om die gesag van die Skrif 
aan te tas. Die sentrale teoretiese argument is dat ekstremisme vermy kan word indien ' $n$ veelheid van metodes in teologiebeoefening aangewend word - in hierdie geval metodes wat outeur-, teks- en lesergeoriënteerd is. 'n Aanvaarbare teologiese raamwerk behoort geskep te word om die teoloog in staat te stel om die Bybel sodanig te interpreteer dat teologiese gevolgtrekkings gekontroleer en eensydighede vermy kan word. So 'n teologiese raamwerk behoort die volgende aspekte te verreken: die relasionele fokuspunt van die Skrif, die kontoere van die Skrif self en die historiese aard van die Skrif. 'n Gebalanseerde verhouding tussen die Goddelikheid en die menslikheid van die Skrif moet gehandhaaf word vanuit die perspektief van die verbond. In die kontekstualisering van die Skrif moet die Skrif nie as 'n geslote dokument met klinkklare antwoorde beskou word nie, maar as 'n paradigmatiese dokument wat basiese riglyne stel vir die wyse waarop hedendaagse probleme benader kan word.

\section{Inleiding}

Teologiebeoefening het deur die loop van die geskiedenis gereeld in uiterstes van fundamentalisme, rasionalisme en relatiwisme verval. In Suid-Afrika word die teologiese toneel tans, meer as tevore, gekenmerk deur ekstremistiese teologiebeoefening. Hierdie uiterstes in teologiebeoefening word weerspieël in die vurige teologiese debatte oor die historiese betroubaarheid van die opstanding van Christus, die opkoms van fundamentalistiese groepe en die ultrarasionalistiese verskynsel van die Nuwe Hervorming.

In hierdie artikel word gepoog om vanuit 'n gereformeerde teologiesdogmatiese hoek 'n bydrae te maak tot die soeke na 'n interpretatiewe raamwerk wat teologiese ekstremisme kan vermy. Ondersoek sal ingestel word na enkele ontwikkelings binne die hermeneutiese Bybelwetenskappe waarvan die gereformeerde dogmatiek kennis behoort te neem. Die vraag wat in hierdie artikel ondersoek word, is hoe die gesag van die Bybel as die Woord van God gehandhaaf kan word, sonder om in fundamentalisme of relatiwisme te verval en sonder om kritiese vrae oor die Bybelteks te vermy.

\section{Skrifgebruik en teologiese ekstremisme}

Alvorens 'n alternatief op teologiese ekstremisme gebied kan word, is dit nodig om te let op die uitstaande kenmerke van 'n ekstremistiese hantering van die Skrif. Drie ekstreme teologiese benaderingswyses kan onderskei word, naamlik die fundamenta- 
lisme, die rasionalisme en die relatiwisme. Die bedoeling van hierdie artikel is om sekere wesenlike kenmerke van hierdie benaderingswyses aan te toon en nie om 'n uitvoerige klassifisering te gee van teologiese strominge wat hierdie verskynsels kenmerk nie. Die meeste teologieë sal in verskillende mate kenmerke van hierdie verskynsels vertoon.

\subsection{Fundamentalisme}

Fundamentalisme is ' $n$ veelvormige verskynsel wat sigself op politieke, sosiale, ekonomiese en religieuse terreine manifesteer. Gewoonlik is fundamentalisme 'n teenreaksie op sosiale marginalisering, persoonlike isolasie en die verlies van kulturele en etniese identiteit. Fundamentalisme is 'n universele verskynsel wat - in reaksie teen die modernisme - streef na die sekuriteit van ewige waardes, 'n stabiele wêreldbeskouing en die handhawing van tradisies (De Smidt, 1998:37).

Christelike fundamentalisme word gewoonlik terugherlei na twintigste-eeuse ontwikkelings in Noord-Amerika waar die term sy oorsprong het (Van Wyk, 2002:602). In dié tydperk het 'n beweging in die Verenigde State van Amerika ontstaan wat die ortodokse teologie teen die liberale teologie en die modernistiese verskynsels van ewolusionisme, rasionalisme en idealisme wou beskerm deur terug te gryp na die idees van die sewentiende-eeuse Protestantse Ortodoksie (Deist, 1989:2; Van Wyk, 2002:602). Die bedoeling van dié beweging was om op grond van die onfeilbare Skrif 'n onweerspreekbare fondament vir die Christelike geloof te lê.

Dit is noodsaaklik dat die term fundamentalisme genuanseerd gebruik moet word. In kritiese teologiese kringe word hierdie term dikwels misbruik om teologiese konserwatiewe denke te stereotipeer (De Smidt, 1998:39). Hiervolgens is die siening dat die Skrif die Woord van God is, per se fundamentalisties. Dié uitgangspunt kom daarop neer dat teologiebeoefening binne baie kerklike tradisies as wetenskaplik onaanvaarbaar afgemaak moet word. Verder toon die sienswyse van die kritiese teologie ook 'n gebrek aan selfkritiek, omdat selfs die kritiese teologie geloofsuitgangspunte bevat waaroor nie wetenskaplik besin kan word nie (Van Wyk, 2002:593-620).

Ten opsigte van die Skrifleer is 'n fundamentalistiese gebruik van die Skrif nie 'n hedendaagse verskynsel nie, hoewel die benaderingswyse van die Christelike fundamentalisme 'n twintigste-eeuse verskynsel is. Verskillende vorme van fundamentalistiese Skrifgebruik word deur die loop van die geskiedenis gevind. 


\section{- Die siening van die inerrantisme}

Hoewel die Christelike fundamentalisme - as beweging - aan die begin van die twintigste eeu ontstaan het, is ' $n$ fundamentalistiese Skrifgebruik niks nuuts nie. Verskillende vorme van fundamentalistiese Skrifgebruik is deurlopend van die geskiedenis gevind.

Skynbare teenstrydighede in die Skrif word gewoonlik deur inerrantiste by wyse van ooreenstemming van gegewens verklaar. Wanneer twee uitsprake na dieselfde saak verwys, moet die uitsprake noodwendig in substansie ooreenstem (Du Plessis, 1987: 12). Die vraag is egter of die gesag van die Skrif nie deur hierdie benaderingswyse afhanklik gemaak word van 'n menslike teorie nie (Ouweneel, 1995:4). Waarom is tegniese verskille in die Skrif noodwendig 'n bedreiging vir die gesag van die Skrif? Die Skrif is immers nie 'n wetenskaplike handboek nie, maar 'n geloofsboek. Die gesag van die Skrif is nie afhanklik van 'n foutlose opskrifstelling nie, maar is juis sodanig dat dit ondanks menslike foute steeds God se gesagvolle woord is (Kruger, 1993:589).

\section{- Die ontmensliking van die Skrif}

Fundamentaliste beklemtoon die goddelike aard en eienskappe van die Skrif tot so 'n mate dat die menslike sy van die Skrif nie tot sy reg kom nie (Berkouwer, 1966:17). Origines en ander teoloë na hom het die goddelike aard en eienskappe van die Bybel beklemtoon ten koste van die menslike aard. Origines en sy navolgerers het naamlik die allegoriese eksegetiese metode ontwikkel wat na goddelike woorde agter die menslike woorde gesoek het (Silva, 1996:40). Die Protestantse Ortodoksie van die sewentiende eeu het weer die sola scriptura-beginsel van die Reformasie rasioneel probeer regverdig deur die ontwikkeling van die meganiese inspirasieteorie. Hiervolgens sou God self elke woord aan die Bybelskrywers voorgesê het. Hierdie teorie het egter gou probleme opgelewer, omdat die verskillende skryfstyle in die Skrif so 'n teorie weerspreek het. Die meganiese inspirasieteorie is daarom vervang met ' $n$ verbale inspirasieteorie. Daarvolgens het die skrywer wel sy eie styl, maar die woorde is deur God "geadem" en daarom onfeilbaar (Deist, 1989:3). Deur die ontmensliking van die Skrif ontken die fundamentalisme die menslike wyse waarop die Skrif in die werklikheid ontstaan (Berkouwer, 1966:25). 


\section{- Die monistiese en a-historiese benaderingswyse}

Die Bybel en sy inhoud word dikwels in fundamentalistiese kringe gehanteer as een stelsel sonder teenstrydighede. Alle Skrifgegewens word op dieselfde vlak geplaas, terwyl geen onderskeid tussen kern en periferie gemaak word nie. Die Bybelteks word gevolglik oorvra en dikwels buite konteks aangehaal. Skrifbewyse word gebruik sonder dat die literêre aard, gerigtheid en breëre verbande van Skrifgedeeltes verreken word. Nuwe-Testamentiese verbande word oppervlakkig in Ou-Testamentiese teks ingelees, terwyl die Ou Testament op 'n lukrake, a-historiese wyse tipologies en eksemplaries verklaar word. Kultuurhistoriese gegewens en die situasiegerigte aard van die Skrif word nie voldoende verreken nie. Sodoende word die gesag van die Skrif inderwaarheid bedreig, omdat so 'n benadering tot misbruike kan lei.

\section{- Die beklemtoning van die openbaringspositiwisme}

'n Fundamentalistiese neiging wat dikwels in gereformeerde kringe voorkom, is om die menslike interpretasie van die Skrif gelyk te stel aan die openbaring van God. Die gevolg is dat die interpreteerder onkrities omgaan met sy eie voorveronderstellings. Objektiewe toegang tot die outeursbedoeling word as haalbaar beskou, omdat die interpreteerder gelei word deur die Heilige Gees. Bavinck (1928:563) wys tereg daarop dat die getuienis van die Heilige Gees nie eensydig op die gesag van die Skrif betrek moet word nie. Die werking van die Heilige Gees is nie gerig op objektiewe leerstellings nie, maar om gelowiges tot kindskap en aanvaarding van God te bring. Die werk van die Heilige Gees het nie die Skrif en sy interpretasie as sodanig ten doel nie, maar wel Christus en sy middelaarswerk; die werk van die Heilige Gees impliseer daarom nie 'n objektiewe dimensie nie, maar wel 'n persoonlik-subjektiewe dimensie.

\section{- Onverdraagsaamheid en geslotenheid as tiperend van fundamentalistiese strominge}

Fundamentalistiese strominge werk met 'n skerp onderskeid tussen waarheid en valsheid en is daarom geneig om in geslote en eksklusiewe denkstelsels te verval - denkwyses wat gepaard gaan met tradisionalisme en ortodoksisme. Vooruitgang in die teologie word gesien as 'n bedreiging vir die ewige waarhede in die Skrif. Fundamentaliste verset hulleself daarom veral teen die metodes van die hedendaagse kritiese teologie. Die gevaar van die fundamentalisme lê juis in sy geslotenheid. Teologiese interpretasies word maklik verkanoniseer en gesien as direk geïnspireer deur die Gees, 
terwyl opponerende sienings tot valsheid verklaar word. Wanneer kardinale dogmas ter sprake kom, sien die fundamentalisme geen ander opsie as om oor te gaan tot nuwe kerklike formasie nie (Van Wyk, 2002:603).

\subsection{Die invloed van rasionalistiese teologiebeoefening}

Die uitstaande kenmerk van rasionalistiese teologieë is dat hulle poog om deur wetenskaplike metodes na die objektiewe betekenis van die teks te soek. Die rasionalisme toon 'n verset teen dogmatiese teorieë wat as uitgangspunt vir Skrifinterpretasie gebruik word; ook verwerp die rasionalisme die formulering van dogmatiese denkstelsels wat die eenheid van die Skrif as vertrekpunt neem. Enkele rigiede gebruike van die histories-kritiese metode, die New Criticism-rigting en die strukturalisme kan as voorbeelde van 'n rasionalistiese Skrifgebruik genoem word. Hierdie metodes bevat egter ook waarheidsmomente wat deur teoloë op 'n geldige wyse gebruik kan word sonder om in uiterste vorme van rasionalisme te verval.

Die kritiese teologie het ontstaan na aanleiding van die natuurwetenskaplike wêreldbeeld wat met die Verligting ontstaan het. Twee verskuiwings in wetenskaplike navorsing het tot die ontwikkeling van kritiese metodes gelei.

- Eerstens het die natuurwetenskappe die antieke wêreldbeeld van die Skrif aan die lig gebring. Die kritiese teologie het op grond hiervan die rasionalistiese wêreldbeskouing van die Verligting oorgeneem, asook metodes vanuit die natuurwetenskappe. Kousale wette wat met 'n oorsaak-gevolg-skema werk, is as uitgangspunt geneem en supranatuurlike verhale in die Bybel is bevraagteken (Poytress, 1996:451; Prinsloo, 1988:200).

- Tweedens is die opeenvolging van bronne in die Bybel as verkeerd bewys. Die siening het ontstaan dat die Skrif nie met dogmatiese vooroordele gelees moet word nie, maar dat alleen die menslike rede oor die waarheid van die Skrif kan oordeel (Berkouwer, 1966:10-11; Prinsloo, 1988:198). Die konsep van die gesag van die Skrif is op grond van die beklemtoning van die menslike rede drasties verander: geloof is afhanklik gemaak van die wetenskap wat op grond van historiese navorsing die gesag van die Skrif kon beoordeel. Die kritiese teologie neem op grond van die nadruk op die rede dieselfde maatstaf as die fundamentalisme as uitgangspunt: as die Skrif nie 'n histories-objektiewe weergawe gee nie, is dit noodwendig onbetroubaar. 
Die historiese kritiek het Bybelliteratuur op 'n diachroniese wyse bestudeer deur die historiese ontwikkeling van die Bybelteks te probeer rekonstrueer. Daar is gesoek na die volgorde van gebeure waarna die teks verwys en na die historiese wordingsproses van die teks self. Die voorveronderstelling was dat die ware betekenis in die oorspronklike bedoeling en konteks van die outeur gesetel is en dat latere redaksionele wysigings en byvoegings daardie betekenis verander (Longman, 1996:109). Die historiese kritiek benader die Bybelse teks met die volgende kritiese aannames:

- dat gebeurtenisse waarna 'n teks verwys, dalk nie plaasgevind het nie;

- dat die teks op 'n ander tyd of deur 'n ander persoon geskryf kon gewees het as wat die teks self voorgee;

- dat teenstrydighede in die Bybelteks nie in ooreenstemming met ander Skrifgedeeltes verklaar, of "weg"-verklaar moet word nie (Long, 1996:361).

Verskeie histories-kritiese tegnieke is gebruik om die oorspronklike bedoeling van die outeur te vind, waaronder die tegniek van bronnekritiek, vormkritiek en redaksiekritiek.

- Die tegniek van bronnekritiek het, veral ten opsigte van die Pentateug, probeer om die verskillende bronne wat die finale teks onderlê het, te identifiseer, te omskryf en te dateer.

- Die metode van vormkritiek weer het Bybelse gegewens probeer klassifiseer op grond van struktuur, taal en inhoud. Sodoende is probeer om die verskillende stadia in die ontstaan van literêre eenhede te onderskei.

- Met die tegniek van redaksiekritiek word die finale vorm van die teks bestudeer en gesoek na die beginsels wat gebruik is om geïsoleerde tekste saam te voeg (Longman, 1996:109; Bruce, 1977:54).

Op hierdie wyse het die voorstanders van die histories-kritiese interpretasiemetode probeer om te bepaal wie die outeur is, wat die outeur kenmerk, en wat sy oorspronklike historiese konteks is (Longman, 1996:110).

Die metode van historiese kritiek het 'n belangrike bydrae gelewer om die historiese elemente en ontwikkeling van die Skrif beter te verstaan. Die aandag is gevestig op die verskillende fasette van 
tekste, die oorlewering van tekste en die historiese en geografiese konteks waarbinne tekste ontstaan en gefunksioneer het (Volschenk \& Van Aarde, 2002:216). Die histories-kritiese interpretasiemetode openbaar egter fundamentele tekortkominge:

- Die Bybelteks is deur die histories-kritiese metode verhistoriseer. Baie klem is geplaas op die historiese oorsprong van die Skrif ten koste van 'n fokus op die teologiese boodskap van die Skrif.

- Kleiner gedagte-eenhede is intensief bestudeer, terwyl die groter geheel in die Skrif verwaarloos is (Volschenk \& Van Aarde, 2002:231).

- Die Skrif is gereduseer tot 'n historiese en menslike dokument met min kontekstuele waarde. Veral in die na-oorlogse samelewing het teoloë besef dat die histories-kritiese metode min leiding gee ten opsigte van 'n lewens- en wêreldbeskouing wat die problematiek van die hedendaagse mens betrek.

Met die opkoms van die postmodernisme het die rasionalistiese vertrekpunte van die histories-kritiese benaderingswyse verder in die spervuur gekom. Die historiese kritiek het op 'n onkritiese wyse die positivistiese metodes van die natuurwetenskappe oorgeneem. Die vraag is of natuurwetenskaplike metodes gebruik kan word om Bybelliteratuur te bestudeer. Verder het die historiese kritiek met sy idee van objektiewe wetenskapsbeoefening die invloed van voorveronderstelllings op die interpreteerder onderskat. Die menslike rede kan nie as 'n absolute maatstaf vir die vasstel van die "waarheid" dien nie, omdat die menslike rede nie tot volkome objektiwiteit in staat is nie. Historiese navorsing word byvoorbeeld beïnvloed deur die navorser se siening van wat geskiedenis is, wat histories moontlik is en met watter standaarde die historiese aansprake van die teks benader moet word (Poytress, 1996:441). Ondanks sy rasionalistiese uitgangspunte het die histories-kritiese metode deur sy soeke na die bedoeling van die oorspronklike outeur juis in spekulatiewe aannames verval, omdat dit in die meeste gevalle onmoontlik is om die historiese situasie en die groeiproses van die teks te rekonstrueer (Prinsloo, 1988:203). Ten einde die teologie te bevry van kerklike tradisies het die historiese kritiek die teologie onderwerp aan die filosofiese uitgangspunte van die rasionalisme, die anti-supranaturalisme en die moderne humanisme (Poytress, 1996:442).

Sedert die veertiger- en vyftigerjare het die New Criticism en die strukturalistiese benadering ontwikkel in reaksie teen die outeurs- 
gerigte benadering van die historiese kritiek se teksgeoriënteerde benaderings. Voorstanders van die New Criticism en die strukturalisme het egter nie daarin geslaag om rasionalistiese elemente te vermy nie. Terwyl die vormkritiek klem gelê het op die verskillende dele en bronne waaruit 'n teks bestaan, het die New Criticism gefokus op die Bybelteks as geheel (Longman, 1996:100). Die New Criticism het die belang van historiese navorsing en 'n soeke na die oorspronklike bedoeling van die outeur ontken en eerder klem gelê op die selfgenoegsaamheid van die teks. Volgens die voorstanders van die New Criticism is betekenis in die teks self geleë en kan die "betekenis" deur 'n komplekse analise van die konvensies in die teks gevind word (Longman, 1996:111). In die laat-vyftigerjare het die invloed van die New Criticism as 'n dominante faktor in literêre studies begin verdwyn.

Die strukturalisme was 'n meer invloedryke, teksgeoriënteerde beweging wat vanuit die linguistiek ontwikkel het. Soos met die New Criticism soek die die beoefenaar van die strukturalisme die betekenis van die teks nie in die oorspronklike bedoeling van die outeur of in die belange van die lesers nie, maar wel in die gemeenskaplike gebruik van literêre konvensies. Strukturalisties beskou, bestaan taal uit 'n samehangende stelsel van tekens en daarom verdien sinchronie voorkeur bo diachronie. Die strukturalisme het baie klem gelê op wetenskaplike metode en die formulering van 'n presiese analitiese model. Sodoende is gepoog om 'n objektiewe dimensie aan literêre ondersoeke te gee deur 'n paradigmatiese metode te ontwikkel wat die betekenisse van tekste kan ontsluit. In dié proses is baie klem gelê op die funksie van intertekstualiteit. Intertekstualiteit impliseer dat die skrywer van 'n werk die literêre konvensies wat in ander literatuur gebruik word, aanwend sodat ' $n$ teks eintlik ' $n$ konglomeraat van ander tekste is (Longman, 1996:114). Die leser wat weet hoe hierdie konvensies in die literatuur gebruik word, kan die betekenis van die teks verstaan. Die interpretasie van 'n teks word sodoende bepaal deur 'n kode van literêre konvensies en is gevolglik 'n reëlbepaalde proses (Longman, 1996:115).

Dié literêre benaderings het baie bygedra tot die ontdekking van die literêre konvensies wat in die Bybelteks gebruik word, maar het verval in rasionalisme, omdat dié benadering 'n onsensitiwiteit het vir die invloed wat die interpreteerder se verstaanshorison op die betekenis van die teks het. Interpretasie is nie 'n objektiewe reëlgedrewe proses nie. Terselfdertyd verval dié benadering in 'n vorm van a-historisiteit deurdat die oorspronklike bedoeling van die outeur en die historiese oorwegings van die Skrif geïgnoreer word. Die 
Bybel maak immers historiese aansprake en sal 'n onreg aangedoen word as historiese aansprake geïgnoreer word (Long, 1996:378).

\subsection{Die invloed van die relatiwisme}

Lesersgeoriënteerde teologieë is dikwels geneig tot relatiwisme, omdat die outeursbedoeling en die eiesoortige literêre elemente van Bybelliteratuur buite rekening gelaat word. Onder lesersgeoriënteerde teologieë kan kontekstuele bevrydingsteologieë en postmoderne teologieë gereken word.

Kontekstuele teologieë word gekenmerk deur 'n doelbewuste ideologiese benadering tot die teks. Die konteks van die interpreteerder word as die bepalende faktor vir die uiteindelike interpretasie gebruik. Menslike ervaring en eksistensie is die norm, terwyl die Skrif net as 'n bron vir ervaring kan dien. Moderne sosiale analises word as hermeneutiese sleutels gebruik om metafisiese konsepte in die Skrif sogenaamd te ontmitologiseer (Vorster, 2003:214). Op hierdie wyse gebruik die bevrydingsteologie die ervaring van armes, die dinamistiese geskiedenisbeskouing van Hegel en die Marxistiese filosofie van selfbevryding as sosiale analises om die verhouding tussen die interpreteerder se historiese konteks en die Skrif te bemiddel (Vorster, 2003:213). Die feministiese teologie neem weer vroue se ervaring van onderdrukking en vervreemding as ideologiese uitgangspunt. Histories-kritiese metodes word gebruik om androsentriese taal in die Bybel te ontmasker en om die Bybelse narratief vanuit ' $n$ vroulike perspektief te rekonstrueer (Fiorenza, 1984:19).

'n Gemeenskaplike kenmerk van die bevrydingsteologieë is dat die Skrif met 'n hermeneutiek van agterdog benader word (Bird, 1994: 325). Die interpreteerder se ervaring lei tot agterdog teenoor die teks se ideologiese verklarings van die werklikheid. Hierdie ideologiese agterdog word dan op ideologiese superstrukture toegepas. Hierdie benadering lei tot 'n nuwe ervaring van die teologiese realiteit en agterdog jeens aanvaarde eksegetiese benaderings. Op sy beurt lei hierdie benaderingswyse weer verder tot die ontwerp van 'n nuwe hermeneutiek met nuwe elemente om die Skrif in die lig van ervaring te lees (Hennely, 1990:xii). Die geskiedenis word sodoende geïnterpreteer as die outentieke openbaring van God, terwyl die ervaring van die gemeenskap die interpretasie van die Skrif bepaal (Ratzinger, 1990:370-371). Die Skrif word gesien as 'n oop teks wat as 'n model vir ervaring dien, eerder as 'n normatiewe openbaring van ewige waarhede. 
Kontekstuele bevrydingsteologieë het baie bygedra om die aandag op politieke, ekonomiese en sosiale geregtigheid te fokus. Die kontekstuele belang van die Bybelteks is ook beklemtoon in teenstelling met benaderings wat te veel klem gelê het op die outeursbedoeling en die teks se konvensies. Die probleem met kontekstuele bevrydingsteologieë is egter dat bepaalde ideologiese uitgangspunte verabsoluteer word. Sodanige verabsolutering lei daartoe dat nuwe fundamentalistiese raamwerke geskep word wat seksionele belange dien en eerder eksklusief as inklusief te werk gaan. 'n Teologie wat byvoorbeeld uitsluitlik fokus op politieke bevryding deur die geweldadige omverwerping van strukture, kan maklik 'n bedreiging vir ander groepe se belange word. Verder ontneem kontekstuele teologieë die Bybel van sy normatiewe gesag deur dit in diens van ideologiese raamwerke te gebruik. Die gevolg is dat sinkretisme 'n wesenlike gevaar in kontekstuele teologieë word (Swanepoel, 1993:70).

Die postmodernistiese teologie verval gewoonlik in ekstreme relatiwisme. Kenmerkend van die postmodernisme is die aanvaarding van die onvoltooidheid van menslike denke en definisies. Ook word die metaforiese en pluralistiese aard van die menslike bestaan aanvaar. Belangrike eienskappe van die postmodernisme is dat dit fundamentalisme, totalitarisme en mistifisisme nie duld nie (Adam, 1995:7). Volgens die postmodernisme is wetenskaplike funderings onnodig, omdat die mens die werklikheid nie volkome kan ken nie. Totaliteite moet ook teëgestaan word, omdat die mens nie universeel geldige aansprake kan maak nie. Denkrigtings en benaderingswyses soos bemiddel deur onder andere die wetenskap, die rede en politieke stelsels moet gedemistifiseer word, omdat niemand absolute aansprake kan maak nie. Die postmodernistiese teologie is daarom wesenlik anti-fundamentalisties van aard. Teologiese konstruksies word gedekonstrueer en die ideologiese aard van alle uitsprake word aangedui (Du Toit, 1988:36-37). In die postmodernistiese teologiebeoefening word alle teologiese uitgangspunte as arbitrêr beskou; daarom kan teologiese uitgangspunte nie op waarheid aanspraak maak nie, maar alleen op geldigheid. Binne die postmodernisme word selfs bewerings soos die volgende gemaak: die Bybel self bevat geen meta-narratiewe nie en is inherent teenstrydig (Adam, 1995:18); die Bybel is ' $n$ oop kanon, want geen laaste magsaanspraak is moontlik nie; die Bybel moet daarom oorgeskryf en voortdurend geherinterpreteer word, omdat elke waarheidsaanspraak opnuut weer gedekonstrueer word (Du Toit, 1988:45). Ook word gestel dat die oorspronklike bedoeling van die outeur irrelevant is, aangesien dit nie aangedui kan word nie 
- enige beskrywing van die oorspronklike bedoeling van die outeur is eintlik die interpreteerder se idee van wat die outeursbedoeling is (Adam, 1995:20).

Kenmerkend van die postmodernisme is sy agterdog teenoor die vermoë van taal om die werklikheid te beskryf. Du Toit (1988:39) stel byvoorbeeld dat taal nie epistemologiese toegang tot die werklikheid kan bied nie, omdat die werklikheid nie geken en in taal vasgelê kan word nie; taal kan daarom nie 'n draer wees van die diepste waarhede nie. Volgens die postmodernistiese siening bestaan daar geen vaste verhouding tussen taaltekens en die werklikheid nie. Taal bedek meer as wat dit onthul; daarom moet taal ontmitologiseer word (Du Toit, 1988:41). Die gevolg is dat die postmodernisme gebruik maak van die tegniek van dekonstruksie 'n benaderingswyse wat die teks met agterdog bejeën en die magsaansprake van die teks dekonstrueer. Die dekonstruksie as interpretasietegniek verset sigself teen die idee dat 'n "korrekte" metodiek - op grond van die bestudering van woorde en die samehang van woorde - die objektiewe betekenis van die teks kan aandui. Volgens die dekonstruksie is daar geen absolute verwysingspunte soos die outeur, die teks, die antieke, sosiale konteks of ware historiese gebeure wat geld vir 'n aanvaarbare Bybelinterpretasie nie. Betekenis is iets wat die interpreteerder skep, en nie 'n gegewe wat die teks self bied nie (Adam, 1995:33). Juis daarom kan die Bybel op geen absolute gesag aanspraak maak nie.

Die postmodernisme se uitgangspunte skep probleme, omdat dit feitlik vir enige doelwitte misbruik kan word. Wanneer alle interpretasies van die teks ewe geldig is, verloor die teks self sy konstruktiewe invloed. Deur dekonstruksie word die teks afgebreek sonder dat konstruktiewe alternatiewe gebied word (Nurnberger, 2000:295, 311). Die postmoderne teologie lei inderdaad tot 'n nihilistiese en etieklose teologie wat geen morele leiding aan die samelewing gee nie. Die feit dat ons slegs gedeeltelik kan ken, beteken nie dat ons moet ophou soek na waarheid nie.

Die gevaar van relatiwistiese teologie is dat die Bybelteks self sy konstruktiewe waarde verloor, met die gevolg dat die teks misbruik kan word vir ideologiese doeleindes.

\section{Die noodsaak vir 'n interpretatiewe raamwerk}

Teologiese ekstremisme ontstaan wanneer een interpretasiemetode as die enigste aanvaarbare metode voorgehou word. Daarom moet eensydige benaderings vervang word deur ' $n$ multidimensionele 
benadering wat die geldige momente in die verskillende interpretasiemetodes herken, maar ook die leemtes van elke metode uitwys. Die veronderstelling is dat Bybelinterpretasie outeurs-, teksen lesersgerig moet wees.

Die outeursbedoeling bly 'n belangrike verwysingspunt wat kan help om relatiwisme teen te werk. Hoewel dit onmoontlik is om die oorspronklike outeursbedoeling volkome weer te gee, kan 'n betroubare beeld wel deur verantwoordelike eksegese verkry word. Die outeur het immers beoog om 'n bepaalde boodskap op 'n verstaanbare wyse aan sy gehoor oor te dra. 'n Teksgeoriënteerde benadering kan help om die literêre aard van die Skrif en die funksies van verskillende literatuursoorte in die Skrif beter te verstaan, terwyl 'n lesersgeoriënteerde benadering kan bydra tot 'n beter verstaan van die invloed van kontemporêre gebeure op hedendaagse lesers se verstaan van die Skrif. Op grond van 'n multidimensionele benadering kan eensydighede vermy en die geldigheid van teologiese gevolgtrekkings beter gekontroleer word.

So 'n hermeneutiese raamwerk moet egter aangevul word deur 'n teologiese raamwerk, wat rigting gee aan die interpreteerder se gebruik van die Skrif. Die Skrif is 'n eiesoortige bron wat nie uitsluitlik deur middel van sekulêre, filosofies-hermeneutiese middele bestudeer kan word nie - met sodanige interpretasiemetodes word die eiesoortige aard en gesag van die Skrif ondermyn. In die interpretasie van die Skrif sal 'n eie teologies-filosofiese interpretasietradisie ontwikkel moet word.

In die proses van Skrifverklaring duik teologiese vrae op wat filosofiese en teologiese besinning vereis. Hierdie vrae sal die interpreteerder se benadering tot die Skrif op 'n fundamentele wyse beïnvloed. Sulke vrae sluit die volgende in:

- Watter rol speel my voorveronderstellings in my interpretasie van die Skrif?

- Is die Skrif 'n menslike geskrif, Goddelike geskrif, of is dit sowel menslik én Goddelik?

- Is die Skrif 'n teologiese eenheid of is dit 'n geskrif met dokumente wat verskillende teologiese aansprake verteenwoordig?

- Het die Skrif 'n kernboodskap?

- In watter lig moet oneffenhede in die Skrif verstaan word? 
- Kan die antieke wêreldbeeld van die Skrif versoen word met die hedendaagse wetenskaplike wêreldbeeld?

- Is die etiese riglyne van die Skrif geldig vir vandag?

Vele soortgelyke vrae kan ter sprake kom.

Die Skrif kan self op sekere van hierdie vrae lig werp. Die interpreteerder moet bereid wees om sy geloofsvoorveronderstellings te laat korrigeer deur sy omgang met die teks. Desnieteenstaande kan sommige vrae egter net deur filosofiese en teologiese besinning bespreek word. Skrifinterpretasie sal altyd 'n relatiewe element bevat, omdat geloofs- en filosofiese uitgangspunte 'n bepalende invloed op Skrifinterpretasie het.

Vervolgens sal vanuit 'n gereformeerd-dogmatiese perspektief besin word oor 'n moontlike teologiese raamwerk vir Skrifinterpretasie wat kan bydra om teologiese ekstremisme te vermy.

\section{4. 'n Teologiese raamwerk vir Skrifinterpretasie}

\subsection{Die invloed van voorveronderstellings op die verstaan van die Skrif}

Enige verklaring van 'n teks behels noodwendig interpretasie. Geen interpreteerder is in staat om sy stof volkome objektief te benader nie. Pogings om nuwe inligting te verstaan behels dat die interpreteerder sy vroeëre verstaansraamwerk aanpas om die nuwe gegewens daarin te integreer (Silva, 1996:20). Verskeie elemente speel ' $n$ rol in interpretasie:

\section{- Psigologiese eienskappe}

Enige interpreteerder word deur sy persoonlike eienskappe, omgewing en milieu beïnvloed. Persoonlike vooroordele, politieke en kulturele faktore en kerklike en akademiese belange beïnvloed die tipe vrae wat die interpreteerder aan die teks vra.

\section{- Geloofsvoorveronderstellings}

Die interpreteerder se siening van die werklikheid beïnvloed die keuse van die metodiek wat hy gebruik om die Skrif te verklaar. Indien die interpreteerder se werklikheidsbeskouing ruimte laat vir metafisiese konsepte, sal hy groter waarde heg aan die teologiese boodskap en normatiewe waarde van die teks. As die interpreteerder 'n materiële visie op die werklikheid het, sal hy klem lê op 
die menslike aspekte van Bybelliteratuur, metafisiese konsepte probeer ontmitologiseer of as mite afmaak en die normatiewe gesag van die Skrif ontken (Long, 1996:390). Geen teoloog kan hierdie geloofsvoorveronderstellings, wat wetenskaplike nadenke transendeer, vermy nie.

\section{- Wetenskapteoretiese uitgangspunte}

Die interpreteerder se uitgangspunt oor die verhouding tussen geloof en wete en of daar aan een van dié twee prioriteit verleen moet word, sal sy teologie fundamenteel beïnvloed (Van Wyk, 2002:594). Die hermeneutiese metodiek wat navorsers gebruik, bevat verdere filosofiese uitgangspunte oor die aard van taal, geskiedenis, die funksie van bepaalde genres, ensovoorts. Alle feite wat die teoloog bestudeer, is in wese teoriebelaai en vereis daarom interpretasie.

\section{- Kontekstualisering}

Kennis word altyd gekwalifiseer teen die agtergrond van ander kennis (Poytress, 1996:525). Skrifinterpretasie sluit noodwendig 'n mate van kontekstualisering in, omdat die hedendaagse interpreteerder 'n antieke teks vanuit sy eie verstaansraamwerk en vanuit 'n moderne idioom benader (Silva, 1996:30). Terselfdertyd is die oogmerk van Bybelinterpretasie juis om 'n spesieke teks van een historiese konteks na 'n ander te verplaas. Hierdie verplasing maak dit moeilik om die bedoeling van die Bybelskrywer te isoleer van die belang wat die teks vir die interpreteerder self het. Gemeenskappe lees die Skrif vanuit verskillende behoeftes, belange, sosiale konstruksies van die werklikheid en paradigmas wat histories en sosiaal gekonstrueer is en interpreteer die Skrif daarvolgens (Smit, 1994: 273).

\section{- Tradisie}

'n Teoloog se dogmatiese vertrekpunte speel 'n fundamentele rol in sy interpretasie. Elke tradisie beklemtoon sy eie aksente en lees die Skrif vanuit daardie aksente. Dit is belangrik dat teoloë hulle voorveronderstellings openbaar, omdat geen navorser homself van voorveronderstellings kan losmaak nie (Snyman, 1992:264). Interparadigmatiese debat word sodoende vergemaklik, omdat die bydrae wat 'n teoloog maak, beter geëvalueer kan word. Kontak met ander paradigmas kan terselftertyd eensydighede in die interpreteerder se eie paradigma korrigeer. 


\subsection{Die relasionele rigpunt van die Skrif}

Dit is noodsaaklik dat die skopus van die Skrif verreken moet word. Die Skrif het 'n duidelike rigpunt: dit handel oor die verhouding tussen God, mens en aarde. Uit die interaksie tussen God en mens op aarde ontwikkel 'n aantal deurlopende temas wat die boodskap van die Skrif vorm en wat op Christus afstuur (König, 2002:29). Hierdie kerntemas in die Bybel bevat almal 'n sterk relasionele grondslag. Die mens se beeldskap van God dui byvoorbeeld op die mens se vermoë tot 'n verhouding met God; die verbond spel die raamwerk van die verhouding tussen God en die mens uit in terme van beloftes, verpligtings en seën; die koninkryk dui op die dinamiese aard van God se heerskappy oor die mens. Dit is daarom belangrik dat die bestemming van die Skrif voor oë gehou moet word (Berkouwer, 1966:178). Die Skrif is 'n geloofsboek wat die mens in verhouding met God probeer bring.

'n Fokus op die relasionele rigpunt van die Bybel kan enersyds help om die universele kontoere van die Skrif te herken ondanks veranderende kultuursituasies. Andersyds moet die Skrif nie oorvra word met vrae wat buite die gerigtheid en bestemming van die Skrif val nie. Bybelse geskiedskrywing kan byvoorbeeld nie in die lig van hedendaagse wetenskaplike kriteria vir historiese navorsing beoordeel word nie; Bybelse geskiedskrywing het immers 'n teologiese doel en probeer om God se hand agter die geskiedenis te beskryf (Berkouwer, 1966:213; 1967:195). Die redakteurs van Bybelboeke het dikwels uit respek vir hulle bronne nie probeer om verskille in ooreenstemming met mekaar bring nie (vgl. Gen. 1 en 2). Die vroeë Christelike kerk het historiese verskille in die Evangelies geduld, omdat hierdie verskille nie die sentrale boodskap van die evangelie raak nie.

In die Skrif word God, die mens en die aarde in hulle verhouding direk op mekaar betrek, sodat dié verhouding 'n dinamiese aard en eienskap toon (König, 2002:33). Min word oor God geopenbaar buite sy verhouding tot die mens en die aarde, terwyl die mens en die aarde se bestaan beoordeel word in die lig van hulle verhouding tot God.

Die Skrif het 'n teosentriese uitgangspunt. God is die oriënteringspunt vir die verhouding tussen God, die mens en die aarde. Hy is die oorsprong van die relasie (Vader), hou die relasie in stand (Seun) en bepaal die eindbestemming van die relasie (Heilige Gees). Die mens is God se bondgenoot. As beeld van God vertoon die mens bepaalde analogiese ooreenkomste met God, maar ook verskille, 
omdat God in sy wese verhewe is bo die mens. Die mens se verhouding tot God kry gestalte in sy verhouding met sy medemens. Daarom word baie soos-vermanings in die Nuwe Testament gevind. Die mens moet soos God en Christus optree in sy verhouding met sy medemens (König, 2002:39). Die aarde is die terrein waar God en die mens mekaar ontmoet, maar die aarde is ook die objek van God se bemoeienis. Die Skrif beskryf die herskepping van die gebroke aarde ooreenkomstig God se oorspronklike doel met sy skepping.

In die verhouding tussen God, die mens en die aarde is God die konstante faktor, terwyl die mens en die aarde veranderlike faktore is. Die mens is in sy wese sondig, histories gekondisioneerd en bepaald. Die aarde word ingrypend beïnvloed deur die sondige gebrokenheid en het verlossing nodig. God se optrede is konsekwent en getrou, maar die historiese bepaaldheid van die mens veroorsaak dat God in verskillende tye op verskillende wyses met die mens omgaan.

\subsection{Die Goddelikheid en menslikheid van die Skrif}

Daar moet gewaak word teen buite-Bybelse inspirasieteorieë. Die selfgetuienis van die Skrif behoort vir die gereformeerde teoloog as vertrekpunt te dien. Die Skrif handhaaf sigself as die Woord van God. In die Ou Testament word baie klem gelê op die Goddelike gesag van die woorde van die profete en dat God opdrag gegee het dat sy voorskrifte opgeskryf moet word (2 Sam. 23:2; Sag. 7:7, 12; Jer. 15:19; Jer. 30:2-3; Jes. 1:20); Die Nuwe Testament hanteer die Ou Testament as die Woord van God (Heb. 1:1; Hand. 3:21; 2 Pet. 1:21). Die Evangelies beskryf die woorde en werke van Christus self (Luk. 1:3) en die geskrifte van die apostels word in die Nuwe Testament met Goddelike gesag aan die gemeentes voorgehou (1 Kor. 2:1; 2 Kor. 5:20). Die interpreteerder se aanvaarding of verwerping van die Skrif se aansprake op betroubaarheid sal 'n bepalende invloed op die resultate van sy eksegese hê. Verskillende genres in die Bybel maak egter verskillende waarheidsaansprake. Nie alle genres in die Skrif beroep hulleself op historisiteit nie; daarom moet die Bybelteks nie gelees word in terme van aansprake wat dit nie self maak nie.

Die Skrif kan met 'n hermeneutiek van vertroue of agterdog benader word. Die feit dat die Skrif ten opsigte van die hooflyne duidelik en eenstemmig is, die Ou Testament geen heldegeskiedenis bevat nie, die apostels bereid was om te ly ter wille van die boodskap van die evangelie, en daar geen rede bestaan waarom hulle die evangelie 
moes vervals nie, is sterk argumente ten gunste van die betroubaarheid van die Skrif (König, 2002:153-154).

Hoewel die Skrif sy Goddelike oorsprong duidelik stel, getuig die Skrif ook dat God se Woord in 'n menslike gestalte aangebied word (2 Kor. 4:13). Die Skrif is die produk van die verhouding tussen God en die mens. God spreek deur mense tot mense. Om die menslike sy van die Skrif te ignoreer, sou beteken dat die werklikheid van die Skrif ontken word. Dit is belangrik dat 'n gesonde verhouding tussen die Goddelike en die menslike aard en eienskappe van die Skrif gehandhaaf moet word. Wanneer die Goddelike aard en eienskappe van die Skrif oorbeklemtoon word, word alle uitsprake in die Bybel maklik op dieselfde vlak gestel en kan die Skrif misbruik word om enige saak te regverdig. Wanneer die menslike aard en eienskappe oorbeklemtoon word, verloor die Skrif sy normatiewe gesag vir gelowiges.

Die ingewikkelde verhouding tussen God en die mens by die ontstaan van die Skrif behoort in die lig van God se verbond verstaan te word (Doubell \& Strauss, 2001:307). Die verbond vorm die grondslag van die Bybelse waarheidsbegrip (Wentsel, 1981:72). Die Bybel is 'n verbondsboek wat ontstaan het uit die verbond wat God met Israel gesluit het (Eks. 24). In die kern van die verbond staan die wederkerige vertrouensverhouding tussen God en die mens. Die verbond bevat God se beloftes van seën en eise aan die mens, maar ook die reaksie van die mens op God se beloftes. God tree eensydig in 'n verbondsverhouding met die mens, deur Homself in historiese gebeurtenisse te openbaar. Die verbondsmens kan nie anders nie as om op God se dade te reageer deur te bely en te getuig. Nie net openbaar God Homself in historiese gebeurtenisse aan die mens nie, maar Hy gebruik die mens as volledige bondgenoot in sy volle menslike gebrokenheid om die openbaring op te skryf.

In die totstandkoming van die Skrif speel die mens nie alleen 'n instrumentele rol nie, maar ook 'n funksionele rol, want Goddelike openbaring ontmenslik nie die Skrif nie, maar werk deur menslike swakheid, ervarings en konteks heen (Berkouwer, 1967:59; 2 Kor. 3:5-6; 1 Kron. 29:29; 2 Kron. 12:15). Die skrywers van die Bybel dikteer nie God se woorde nie, maar hulle gebruik bronne en orden hulle gegewens op 'n selektiewe wyse, met spesifieke kerugmatiese doelwitte en vir 'n spesifieke gehoor. Hulle werke is nie foutloos nie, bevat tegniese foute, teenstrydighede, oneffenhede en soms verskillende, maar komplementerende teologiese verklarings vir menslike realiteite - byvoorbeeld vir die sin van lyding. Die eind- 
redakteurs van die Ou Testament het die eindteks vasgestel sonder om altyd te probeer om verskille tussen bronne in ooreenstemming met mekaar te bring. Sodoende word die Skrif verryk met 'n verskeidenheid perspektiewe wat uitdrukking is van die diversiteit van die menslike werklikheid. Tog geskied die eindredaksie van die Ou Testament in ooreenstemming met die gees van die verbond, die Tora en die profete (Wentsel, 1981:126). Die Nuwe Testament berus op die grondslag van die nuwe verbond. Christus vertrou sy woorde toe aan sy apostels, wat van die betekenis van Jesus se koms na die wêreld moet getuig. Die vroeë kerk aanvaar die NuweTestamentiese geskrifte, omdat hierdie geskrifte volgens hulle die heilsgebeure op 'n betroubare wyse oordra, soos dit deur die apostels mondeling aan die vroeë kerk oorgelewer is. Hierdie oorgelewerde getuienis van die apostels kom in die Nuwe Testament voor in baie variasies en variante en met verskillende teologiese doelwitte, maar dieselfde hoofverhaal word vertel (Wentsel, 1981: 171). As die inisieerder en onderhouer van die verbond waarborg God die betroubaarheid van die geheelboodskap van die Skrif. Die Heilige Gees gebruik die Skrif om God se verbond aan nuwe geslagte te bevestig. Daarom is die Skrifgegewens nie net die resultaat van God se verhouding met die mens nie, maar ook die instrument waardeur God in nuwe verhoudings met die mens tree.

Hoewel die Skrif God se verbondsboek is, is geloof nie gerig op die Skrif nie, maar op Christus as verbondsmiddelaar. In die sentrum van die Christelike geloof staan 'n Persoon, nie 'n boek nie.

Op grond van die menslike aard en eienskappe van die Skrif, moet sekere komplekse kenmerke van die Skrif in die interpretasieproses verreken word.

\section{- Kanonvorming}

Eerstens moet die probleem van die kanon verreken word. Die vasstelling van die kanon het 'n historiese proses ondergaan waarin menslike oorwegings ' $n$ rol gespeel het. Verskeie probleme in verband met die vasstelling van die kanon bestaan, byvoorbeeld die volgende:

- die apostels het hoofsaaklik die Septuagint gebruik en daaraan dieselfde gesag as aan die Hebreeuse Bybel toegeken;

- daar het waarskynlik meer as een weergawe van die Hebreeuse Ou Testament in die periode van die vroeë kerk bestaan; 
- oor sommige geskrifte (Jakobus, Hebreërs en 2 Petrus) was heelwat twyfel voordat dit in die kanon opgeneem is;

- die Rooms-Katolieke Kerk het 'n ander kanon as kerke vanuit die Protestantse tradisie (König, 2002:24).

Om die sekerheid van die kanon te begrond op formele kategorieë soos die spesiale werking van die Heilige Gees, die apostoliese oorsprong van die Bybelse geskrifte of die gesag van die kerk, is onbevredigend. So 'n kanonvorming kom daarop neer dat menslike betrokkenheid in die kanonvorming ontken word en dat die betroubaarheid van die kanon begrond word op eksterne gronde, wat vaste sekerhede sou bied (Berkouwer, 1966:97). Die gesag van die kanon berus op sy inwendige getuienis. Om vas te stel of sekere boeke met reg in die kanon opgeneem is, moet die reliëf/riglyne van die Skrif in aanmerking geneem word. Die vraag is watter verband ' $n$ boek met die heilshistoriese gang van die Skrif toon? In watter verband staan 'n boek met die boodskap van verlossing in Christus? Die weg tot geloof vir die vroeë kerk was nie vanaf die Skrif tot die toe-eiening van die heilsgebeure nie, maar wel vanaf die toe-eiening van die heilsgebeure na die Skrif. Die vroeë kerk het die kanon vasgestel omdat die boeke wat daarin vervat is, volgens hulle, reg laat geskied het aan die oorlewering van die historiese heilsgebeure. Op die ou einde bevat die proses van kanonvorming 'n relatiewe menslike element. Desnieteenstaande is die feit dat bykans al die kerke deur die loop van die geskiedenis saamgestem het oor die sentrale waarhede van die geloof, 'n aanduiding dat die kanon 'n bevredigende rigsnoer bied (Apostolicum).

\section{- Die historiese konteks van die Skrif}

Tweedens is dit noodsaaklik om die historiese konteks van die Skrif in aanmerking te neem. Die openbaring is nie ' $n$ tydlose, bohistoriese gebeure nie, maar 'n openbaring van God self in die geskiedenis - daarom moet die verhouding van die openbaring tot die geskiedenis verreken word (Berkouwer, 1966:29). 'n Sensitiwiteit vir die historiese aspekte van die Skrif veronderstel dat taal, genre, kultuurhistoriese omstandighede en die geskiedenis van die ontwikkeling van die teks deeglik bestudeer moet word om die wyse waarop God Homself in mensewoorde openbaar, te verstaan. Sosiologiese en argeologiese gegewens kan in die bestuderingswyse sinvol gebruik word. Dit is egter belangrik om te besef dat sosiohistoriese en argeologiese gegewens dikwels fragmentariese gegewens na vore bring wat nie 'n omvattende perspektief bied nie (Long, 1996:375). 
Die historiese aard van die Skrif impliseer dat die Skrif tydgerig is. Die Skrif is immers primêr gerig tot die eerste hoorders, wat met 'n eiesoortige problematiek geworstel het. Hierdie tydsbetrokkenheid van die Skrif kan gesien word in die taal, styl en verskillende Sitzen im Leben van Bybelgedeeltes (Berkouwer, 1967:101). Vanweë die tydsgerigte aard van die Skrif kan nie alle Bybelse voorskrifte direk na die hede herlei word nie, want die Skrif vertoon 'n bepaalde kontinuïteit en diskontinuïteit. König (2002:149) noem drie groepe sake in die Skrif wat as histories afgehandel beskou moet word, naamlik die geosentriese wêreldbeeld in die Skrif, uitgediende sake soos seremoniële wette en etiese kwessies wat in die lig van die koms van Christus onaanvaarbaar geword het (byvoorbeeld die banvloek en swaar strawwe) en insidentele sake wat met die sedes en gewoontes van die tyd te make het (byvoorbeeld vroue wat nie sonder sluiers mag bid nie). Hierdie elemente van diskontinuïteit in die Skrif word reeds duidelik in die wyse waarop die Briewe van Paulus Ou-Testamentiese gegewens hanteer. Paulus beskou byvoorbeeld die seremoniële wette van die Ou Testament as vervul in Christus (Gal. 2:16). Die implikasie is dat die Bybel krities in 'n beoordelende, gelowige sin gelees moet word (krinein) (Berkouwer, 1967:431). Deur te fokus op die historiese aspekte van die Skrif word die boodskap van die Skrif nie gerelativeer nie, maar kom dit eintlik beter tot sy reg. Die universele beginsels in die Skrif benadruk sigself ondanks verskillende historiese omstandighede en verbande.

\section{- Die ontwikkelingsgang van die Skrif}

Derdens is dit nodig om die teologiese ontwikkelingsgang van die Skrif te verreken. Hierdie beginsel hang nou saam met die verstaan van die reliëf van die Skrif. God se verhouding met die mens ontplooi deur die loop van die geskiedenis; daarom is dit noodsaaklik om die ontwikkeling van verskillende teologiese raamwerke binne die Skrif self te verdiskonteer. Voorbeelde van ontwikkelende teologiese raamwerke in die Skrif is die sogenaamde teodiseevraag, die verstaan van die begrip "die dag van die Here", die Messiasverwagting, die funksie van die wet, die verhouding tussen Israel en die kerk, ensovoorts. Twee uitlegmetodes wat hierin behulpsaam kan wees met die vasstelling van die teologiese ontwikkelingsgang is Skrif-met-Skrifvergelyking en heilshistoriese uitleg.

\section{- Die verband tussen die Ou en die Nuwe Testament}

In die vierde plek moet die verband tussen die Ou en Nuwe Testament verreken word. Die Nuwe Testament en die betekenis van die werk van Christus kan nie verstaan word sonder die 
fundamentele leringe wat die Ou Testament bied oor die skepping, die verantwoordelikheid van die mens, die sondeval, verbond en die uitroep tot verlossing nie. Die grootste deel van die Christelike leringe in die Nuwe Testament het die Ou Testament as agtergrond, omdat die verwysingspunt in Christus se prediking die Ou Testament is (Muller, 1996:580). Die Ou Testament moet daarom nie ondergeskik gestel word aan die Nuwe Testament nie. Die Ou Testament moet ook nie allegories verklaar word in die naam van Christosentrisme nie. Die eenheid tussen die $\mathrm{Ou}$ en Nuwe Testament is daarin geleë dat die Nuwe Testament doelbewus op Ou-Testamentiese temas voortbou en dit in die lig van die koms van Christus aktualiseer.

Die Nuwe-Testamentiese skrywers pas Ou-Testamentiese gedeeltes met besondere vryheid op Christus toe. Ou-Testamentiese gedeeltes word gekontekstualiseer om die nuwe konteks, wat met die koms van Christus ontstaan het aan te dui. Soms word woorde verander, tekste word selektief buite hulle historiese verband aangehaal en aanhalings word eksemplaries op Christus toegepas. Vir die Nuwe-Testamentiese skrywers het dit egter nie gegaan oor 'n wetenskaplike besig-wees met die Skrif nie, maar wel oor die sentrale inhoud van die evangelie. Hulle het die Ou Testament gesien as die boek van belofte en die koms van Christus as die vervulling van die beloftes (Berkouwer, 1967:173); daarom het hulle op 'n vrye, vertolkende wyse met die Ou Testament omgegaan. Die feit dat die Nuwe-Testamentiese skrywers nie verwys het na die historiese raamwerk van die profesieë wat aangehaal is nie, beteken nie dat hulle die historiese belang van hierdie tekste ontken het nie (Silva, 1996:80). Die ware inhoud van die Ou Testament word nie aangetas deurdat die historiese raamwerk nie aangehaal word nie, omdat die Ou Testament wel heilshistories op Christus uitloop. Tog is dit nie nodig of wenslik dat moderne interpreteerders omgaan met die Ou Testament soos die Nuwe-Testamentiese skrywers nie enersyds, omdat die Ou Testament se gesag nie van Christosentriese interpretasies afhang nie, en andersyds, omdat 'n vrye, vertolkende benadering tot misbruike kan lei. Die Ou Testament het 'n eiesoortige heilshistoriese gesag en moet allereers binne sy eie konteks verstaan word, alvorens dit op Christus toegepas kan word.

\section{- Antieke wêreldbeelde en mites}

In die vyfde plek kom die problematiek rondom die voorkoms van antieke wêreldbeelde en mites in die Skrif ter sprake. Dit is opvallend dat die sentrale beelde in die Bybel vir die verhouding 
tussen God en die mens 'n duidelike weerspieëling van antieke wêreldbeelde is. Die beeld van die verbond word byvoorbeeld gebruik na analogie van die oud-Kanaänitiese vasalverdrae, terwyl die beeld van die koninkryk gebruik word na analogie van 'n koning wat op 'n absolute wyse oor sy mense heers. Hierdie beelde skep egter nie probleme vir Bybelinterpretasie nie, omdat die boodskap van die beelde duidelik verstaan kan word ondanks sy historiese verpakking. Die vraag is egter watter invloed die antieke drieverdiepingwêreldbeeld (hemel, aarde en onderaardse diepte) het op die sentrale boodskap van die Bybel.

Volgens Bultmann (1987:247-285) verteenwoordig die Nuwe-Testamentiese wêreldbeeld 'n mitiese wêreldbeeld wat nie meer vandag geldig is nie. Hy stel onder andere die volgende: dat die Evangelies se boodskap deur mites gekleur en deur mites uitgedruk word; dat Jesus se wonderwerke, sy opstanding en hemelvaart deel is van 'n mitologiese wêreldbeeld en nie as histories gesagvol beskou kan word nie. Die kerugma in die Bybel gaan egter nie primêr om historiese feite nie, maar dring aan op 'n geloofsbeslissing van die mens. Die mites hoef dus nie uit die Bybel weggelaat te word nie, maar behoort wel krities geïnterpreteer te word. Volgens Bultmann kan mites alleen krities geïnterpreteer word as die Skrif op 'n eksistensialistiese wyse verstaan word. Bultmann voer dus aan dat die vraag nie is of Christus werklik liggaamlik opgestaan het nie, maar wel of Hy in die mens se hart opgestaan het.

Bultmann se benadering skep probleme, omdat hy die historiese belang van die Bybelse boodskap ontken. Indien Christus nie werklik uit die dood opgestaan het nie, word die gebeure van die kruisdood en die versoening wat Jesus Christus bewerk het inhoudloos (Van Wyk, 2002:610). Die waarheid van die Bybelse boodskap staan en val by die historiese waarheid van Jesus se kruisdood en opstanding. Die vraag is of Bultmann nie dalk met verkeerde probleemstellings werk nie. Is die Nuwe Testament se konsep van die werklikheid werklik so primitief as wat hy dink? Die Skrif bied nie 'n eksakte beskrywing van 'n sistematiese wêreldbeeld nie (Wentsel, 1981:206), en hou ook geen antieke wêreldbeeld as normatief voor nie. Baie elemente van mitologiese taalgebruik in die Skrif waarvan Bultmann praat, is inderdaad metafore, simbole en analogieë wat in himnies-getoonsette gedeeltes gebruik word om bepaalde idees in die idioom van die tyd uit te druk (Dunn, 1977: 298; Ef. 4:8, 9; Fil. 2:10, 11 en Op. 5:13). Die wonders van Christus, sy opstanding en hemelvaart is spesifiek gerig op die heilsgebeure en hou verband met 'n Godsbegrip wat die almag van God oor sy skepping beklemtoon en nie met mitiese kosmiese voorstellings nie. 
Dit sou foutief wees om 'n antieke wêreldbeeld met die kerugma van die Skrif te identifiseer. ' $n$ Verdere vraag is of die geslote rasionalistiese wêreldbeeld waarmee Bultmann werk, nie ook maar net so kontekstueel bepaald is as 'n geosentriese wêreldbeeld nie.

\subsection{Die reliëf van die Skrif}

'n Kenmerk van fundamentalisme, rasionalisme en relatiwisme is dat die Bybel gelees word sonder om die reliëf van die Skrif te verreken. Met die reliëf van die Skrif word nie bedoel dat die inhoud van die Skrif gereduseer word tot 'n bepaalde kerninhoud nie, maar wel dat die sentrale gerigtheid van die Skrif in sy verskeidenheid beklemtoon moet word. Die reformatoriese belydenis dat die Skrif duidelik is, beteken nie dat die Skrif in al sy fasette duidelik is nie. Vir die Hervormers het dit gegaan oor die fundamentele waarhede in die Bybel wat noodsaaklik is vir die mens se verlossing (Silva, 1996:64). Alles in die Bybel lê nie op dieselfde vlak nie. Daar is dinge wat oorheers en in die sentrum staan en daar is lyne of trajekte wat die sentrum gaandeweg sterker belig en verduidelik (König, 2002:92). Sommige uitsprake in die Bybel is op 'n spesifieke situasie afgestem, terwyl ander uitsprake 'n universele strekking het. Die vernaamste beswaar teen hierdie onderskeid is gewoonlik dat so 'n onderskeid op menslike willekeur sou berus en dat dualistiese kategorieë op die Skrif afgedwing word. Berkouwer (1967:57) wys egter tereg daarop dat die Skrif self klem lê op bepaalde sentrale waarhede soos vervul in die koms van Christus (1 Kor. 15:4-7). Nie alle uitsprake in die Skrif word deur die Skrif self op dieselfde vlak gestel nie. Paulus hanteer sommige Ou-Testamentiese uitsprake in sy Briewe asof dit nie meer geldig is vir sy tyd nie, hoewel hy die Goddelike gesag van die Ou Testament erken. Dieselfde beginsel geld vir die verhouding van die Nuwe Testament tot die hedendaagse mens. Sommige Nuwe-Testamentiese voorskrifte oor byvoorbeeld die plek van die vrou in die erediens, het die sedes en gewoontes van die Nuwe-Testamentiese tyd as agtergrond en kan daarom nie direk op vandag van toepassing gemaak word nie. Calvyn $(1992: 1,12)$ onderskei self tussen noodsaaklike leerstukke in die Skrif en vraagstukke waaroor verskil kan word sonder om die eenheid van die kerk te skeur.

Die vraag is watter maatstawwe behoort te geld vir die onderskeid tussen kerntemas wat die sentrum van die geloof raak en sake wat nie die sentrum raak nie. König (2002:50) noem vier maatstawwe wat met vrug gebruik kan word: 
- Die saak moet herhaaldelik in die Skrif voorkom.

- Dit moet in verskillende verbande in die Skrif voorkom.

- Die Skrif moet daaraan spesifieke teologiese betekenis gee.

- Dit moet uiteindelik op een of ander manier met Christus in verband staan.

Die Skrif bevat verskeie sulke sentrale temas wat aan bogenoemde maatstawwe voldoen, byvoorbeeld die sentrale tema van die skepping, die mens as beeld van God, die sonde, die wet, verbond, Israel en die volke, verlossing, versoening, die gawe van die Heilige Gees, kerk, regverdigmaking deur die geloof, die opstanding van die liggaam en die voleinding. Hierdie hooflyne van die Bybel word deur ' $n$ verskeidenheid analogieë in die Bybel belig en is met mekaar verweef, sodat die een tema nie sonder die ander verstaan kan word nie. Dit is daarom nie wenslik om 'n teologie uit te bou rondom een tema nie, omdat die ryke verskeidenheid van die Skrif daardeur aangetas word. Dit is juis vanweë die konstante hooflyne in die Bybel dat die kerklike tradisie in staat was om die kernboodskap van die evangelie saam te vat. Die dogmas van die reformatoriese tradisie is immers nie geformuleer op grond van enkele geïsoleerde verse nie.

\subsection{Die dinamiek van die Skrif}

Enige verhouding word gekenmerk deur dinamiese wisselwerking. Die God-mensverhouding het 'n eskatologiese gerigtheid wat ontplooi op weg na God se eindbestemming deur die gang van die geskiedenis. God se beloftes gaan in elke nuwe geslag weer opnuut in vervulling (Wentsel, 1981:80). Die Bybel verskaf nie 'n geslote stelsel van ewig geldende beginsels nie, maar bied 'n paradigma wat die mens deur die verloop van die geskiedenis in konkrete gestaltes moet positiveer. Dié paradigma spreek nie alle hedendaagse vraagstukke aan nie, maar verskaf tog religieuse grondmotiewe wat die basiese riglyne vir die ontplooiende verhouding tussen God en die mens vorm. Wanneer die kerk voor nuwe etiese vraagstukke te staan kom, kan sy inspirasie ontvang vanuit die grondliggende gebeurtenisse in die verhouding tussen God en mens, soos dit in die Bybel omskryf word. Die taak van die kerkwetenskappe is om binne die riglyne van die Skrif norme en waardes vir die hedendaagse samelewing te bly teenwoordig stel. 'n Kerkgemeenskap wat die Skrifgegewens verontagsaam as 'n fundamentele riglyn vir waarheid en etiese gedrag, sny sigself af van 
sy eie wortels (Nurnberger, 2000:313). In die etiese positivering van die Skrif kan die kerklike tradisie 'n belangrike ondersteunende rol speel, omdat die kerk nooit op 'n tabula-rasa-wyse met vraagstukke kan omgaan nie (Berkouwer, 1967:356). Dit is immers altyd nodig dat geloofsoortuigings ook aan dié van ander getoets moet word.

Die vraag is hoe etiese riglyne in die Skrif op 'n geldige wyse vir vandag gepositiveer kan word. Die volgende maatstawwe behoort as uitgangspunt te dien:

- Etiese besinning moet vanaf die Skrif na die huidige konteks lei en nie vanaf die huidige konteks na die Skrif nie. Alleen dán kan die Skrif 'n kritiese funksie vervul.

- Die belange van God se koninkryk behoort as verwysingspunt gebruik te word.

- Die historiese agtergrond wat sekere Bybelse voorskrifte onderlê, moet so ver as moontlik verreken word. Sommige Bybelse voorskrifte het spesifieke kulturele gebruike as agtergrond en kan daarom nie as ewig geldende beginsels voorgehou word nie.

- Die reliëf van die Skrif moet in aanmerking geneem word, naamlik watter lig die openbaring van sentrale Bybeltemas op 'n etiese vraagstuk werp.

- Die ontwikkelingslyn van die Skrif moet in gedagte gehou word. Die Skrif toon byvoorbeeld 'n bevrydende ontwikkelingslyn ten opsigte van die regte van slawe en vroue - dieselfde bevrydende tendens word egter nie ten opsigte van seksuele gedrag waargeneem nie.

- Alle etiese vraagstukke moet in die lig van die verlossingswerk van Christus beoordeel word, in die besef dat Christus die wet nie kom ontbind het nie, maar wel vervul het.

- Die liefde teenoor God en die medemens moet onderhou word.

\section{Konklusie}

Teologiebeoefening is ' $n$ menslike proses wat altyd ' $n$ mate van relatiwiteit sal vertoon. Tog kan 'n multidimensionele gebruik van metodes en eerlikheid oor voorveronderstellings daartoe bydra om 'n raamwerk te skep waarbinne teologiese gevolgtrekkings gekontroleer en eensydighede vermy kan word. 'n Gebalanseerde omgang met die Skrif is noodsaaklik. Die relasionele fokus van die 
Skrif, die reliëf van die Skrif en die historiese aard van die Skrif moet verreken word. 'n Gebalanseerde verhouding tussen die Goddelikheid en die menslikheid van die Skrif moet gehandhaaf word vanuit die perspektief van die verbond. In die kontekstualisering van die Skrif moet die Skrif nie as 'n geslote stelsel met klinklare antwoorde gebruik word nie, maar wel as 'n paradigma wat basiese riglyne stel waarbinne die verhouding tussen God en die mens ontplooi op pad na God se eindbestemming met die mens en die aarde.

\section{Geraadpleegde bronne}

ADAM, A.K.M. 1995. What is postmodern bibical critisism? Minneapolis: Fortress.

BAVINCK, H. 1928. Gereformeerde dogmatiek. Volume 1. Kampen: Kok.

BERKOUWER, G.C. 1966. Dogmatische studien. De Heilige Schrift. Volume 1. Kampen: Kok.

BERKOUWER, G.C. 1967. Dogmatische studien. De Heilige Schrift. Volume 2. Kampen: Kok.

BIRD, P. 1994. Authority and context in the interpretation of biblical texts. Neotestamentica, 28(3):323-337.

BRUCE, F.F. 1977. The history of New Testament study. (In Marshall, I.H., ed. New Testament interpretation. Essays on principles and methods. Exeter: Oxford University Press. p. 21-59.)

BULTMANN, R. 1987. Faith and understanding. Translated from the German by Louis Pettibone Smith. Philadelphia: Fortress.

CALVYN, J. 1992. Institusie van die Christelike godsdiens. Deel 4. Potchefstroom: CBJF.

DEIST, F.E. 1989. Fundamentalisme. 'n Gereformeerde beoordeling. Theologia Evangelica, 2:2-7.

DE SMIDT, J.C. 1998. Fundamentalism. A historical survey. Scriptura, 64:3749.

DOUBELL, B. \& STRAUSS, S. 2001. Woord van God of woord oor God. Op soek na 'n eietydse Skrifmodel. Nederduitse Gereformeerde Teologiese Tydskrif, 42(3 \& 4):302-314, Sept.

DU PLESSIS, P.J. 1987. Fundamentalisme - ja of nee. Scriptura, 20:1-32.

DUNN, J.D.G. 1977. Demythologizing - the problem of myth in the New Testament. (In Marshall, I.H., ed. New Testament interpretation. Essays on principles and methods. Exeter: Oxford University Press. p. 21-59.)

DU TOIT, C. 1988. Aspekte van die postmodernistiese idioom in die teologie. Theologia Evangelica, 21:36-50.

FIORENZA, E.S. 1984. Bread not stone. The challenge of feminist biblical interpretation. Boston, Phil.: Beacon.

HENNELY, A.T. 1990. General introduction (In Hennely, A.T., ed. Liberation theology: a documentary history. Maryknoll: Orbis. p. xv-xxv.)

KÖNIG, A. 2002. Ek glo die Bybel ondanks al die vrae. Vaste bakens in 'n tyd waarin die Bybel in gedrang is. Lux Verbi: Wellington. 
KRUGER, M.A. 1993. 'n Weg uit die oorheersing van die histories-kritiese metode, fundamentalisme en genitiefteologieë. In die Skriflig, 27(4):583602.

LONG, V.P. 1996. The art of biblical history. (In Silva, M., ed. Foundations of contemporary interpretation. Grand Rapids: Zondervan. p. 289-429.)

LONGMAN, T. 1996. Literary approaches to biblical interpretation. (In Silva, M., ed. Foundations of contemporary interpretation. Grand Rapids, Mich.: Zondervan. p. 97-192.)

MULLER, R.A. 1996. The study of theology. (In Silva, M., ed. Foundations of contemporary interpretation. Grand Rapids: Zondervan. p. 537-667.)

NURNBERGER, K. 2000. Biblical authority between fundamentalism and postmodernism: Elements of an evolutionary hermeneutics. Religion and Theology, 7(3):284-323.

OUWENEEL, W.J. 1995. The credibility of Scripture. Acta Theologica, 1:1-22.

POYTRESS, V.S. 1996. Science and hermeneutics. (In Silva, M., ed. Foundations of contemporary interpretation. Grand Rapids: Zondervan. p. 435-531.)

PRINSLOO, W.S. 1988. Die histories-kritiese metodes in perspektief. Skrif en Kerk, 9(2):196-207.

RATZINGER, J. 1990. Liberation theology. (In Hennely, A.T., ed. Liberation theology: a documentary history. Maryknoll: Orbis. p. 367-375.)

SILVA, M. 1996. Has the church misread the Bible? (In Silva, M., ed. Foundations of contemporary interpretation. Grand Rapids: Zondervan. p. 15-95.)

SMIT, D.J. 1994. A story of contextual hermeneutics and the integrity of New Testament interpretation in South Africa. Neotestomentica, 28(2):265-283.

SNYMAN, G. 1992. Kenteoretiese besinning oor teologiebeoefening aan die Teologiese Skool van Potchefstroom die afgelope twintig jaar. In die Skriflig, 26(2):247-266.

SWANEPOEL, F.A. 1993. Popularising contextual theology. Scriptura, 45:6778.

VAN WYK, J.H. 2002. Fundamentalisme en kritisisme. Nadenke oor Skrifbeskouing en Skrifverklaring - van Augustinus tot Bultmann. In die Skriflig, 36(4):593-620.

VOLSCENK, G. \& VAN AARDE, A. 2002. Die historiese vraag na land en grondbesit in Israel: Die tekortkomings van die historiese kritiek. Hervormde Teologiese Studies, 58(1):212-233.

VORSTER, N. 2003. Kerk en menseregte binne 'n regstaat. Potchefstroom: PSP.

WENTSEL, B. 1981. Het Woord, de Zoon en de dienst. Deel 1. Kampen: Kok.

\section{Kernbegrippe:}

fundamentalisme; teologiese uiterstes

gereformeerde Skrifbeskouing

rasionalisme; teologiese uiterstes

relatiwisme; teologiese uiterstes 
Key concepts:

fundamentalism; theological extremes

rationalism; theological extremes

reformational view of Scripture

relativism; theological extremes 
